\title{
PERBANDINGAN HASIL BELAJAR MATEMATIKA ANTARA PESERTA DIDIK YANG DIBERI TUGAS KELOMPOK DENGAN TUGAS INDIVIDU DI KELAS IX MTs. MADANI ALAUDDINPAOPAO KABUPATEN GOWA
}

\author{
Sitti Mania ${ }^{1}$, Fitriani Nur ${ }^{2}$, Haeriyah Arianti Syahrir ${ }^{3}$ \\ 1,2,3Fakultas Tarbiyah dan Keguruan UIN Alauddin Makassar \\ 1,2,3Kampus II: Jalan H. M Yasin Limpo No. 36 Samata-Gowa \\ E-mail: sitti.mania@yahoo.com¹, fitianinur@uin-alauddin.ac.id², riasyahnia03@gmail.com³
}

\begin{abstract}
Abstrak:
Penelitian ini bertujuan untuk mengetahui perbedaan hasil belajar matematika antara peserta didik yang diberi tugas kelompok dengan peserta didik yang diberi tugas individu. Jenis penelitian ini adalah kuasi eksperimen. Populasi dalam penelitian ini adalah seluruh peserta didik kelas IX. Sampelnya terdiri dari kelas $\mathrm{IX}_{\mathrm{B}}$ dan kelas $\mathrm{IX}_{\mathrm{C}}$. Teknik analisis data yang digunakan adalah statistik deskriptif dan statistik inferensial. Hasil analisis data deskriptif menunjukkan bahwa peserta didik kelas $\mathrm{IX}_{\mathrm{B}}$ memiliki nilai rata-rata kemampuan awal 66,57 dan nilai ratarata posttest 75,53 . Sedangkan, kelas IX $\mathrm{X}_{\mathrm{C}}$ memiliki nilai rata-rata kemampuan awal yaitu 72,97 dan nilai rata-rata posttest adalah 51,50. Hasil analisis data inferensial yaitu; normal dan homogen, sehingga untuk pengujian hipotesis digunakan uji $t$, dan diperoleh $t_{\text {hitung }}=6,194>t_{\text {tabel }}=2,000$ dengan nilai sig. (2-tailed) $<\alpha$ atau 0,000 $<0,05$, sehingga $\mathrm{H}_{0}$ ditolak artinya terdapat perbedaan yang signifikan hasil belajar matematika peserta didik kelas IX MTs. Madani Alauddin Paopao Kabupaten Gowa antara yang diberi tugas kelompok dengan tugas individu. Temuan penelitian menunjukkan bahwa pemberian tugas kelompok lebih efektif dapat meningkatkan hasil belajar peserta didik.
\end{abstract}

\begin{abstract}
:
This study aims to find out: differences in the learning outcomesamong learners who are given group assignments with learners given individual assignments.This type of research is a quasi experimental research. Population in this study were all students of class IX. The sample consisted of class IX $\mathrm{X}_{\mathrm{B}}$ and class IX $\mathrm{X}_{\mathrm{C}}$. Data analysis techniques used are descriptive statistics and inferential statistics.The results of descriptive data analysis showed that the students of class IX had an average initial ability score of 66,57 and a posttest average of 75,53 . Meanwhile, class IX $X_{C}$ had an average initial ability score of 72,97 and a posttest average of 51,50. The result of inferential data analysis utilizing the normality and homogeneity test of both classes which were used as research sample proved to be normal and homogeneous. Therefore, the hypothesis testing used $t$ test whih resulted in $t_{\text {count }}=6,194>t_{\text {table }}=2.000$ with sig score. (2-tailed) $<\alpha$ or $0,000<0,05$. Therefore, the $\mathrm{H}_{0}$ is rejected which means that there is a significant difference between group work and individual work in mathematics learning outcome of the students in IX class Islamic junior high school of Madani Alauddin Paopao Gowa regency. Research findings indicate that giving group tasks more effectively can improve learners' learning outcomes.
\end{abstract}

Kata kunci:

Hasil Belajar Matematika, Tugas Individu, Tugas Kelompok 
DI sekolah guru sering mengajar dengan menggunakan metode ceramah, yaitu menyampaikan pelajaran secara lisan kepada peserta didik. Di akhir pelajaran peserta didik diberi tugas rumah tetapi hasil pelajarannya belum memuaskan. Sesuai hasil wawancara yang dilakukan peneliti dengan guru matematika kelas IX MTs. Madani Alauddin Paopao diketahui bahwa jika ada peserta didik mengganggap pelajaran matematika sangat sulit untuk dimengerti, itu tentunya merupakan hal yang wajar, sehingga setelah gurunya menjelaskan materi tetapi masih ada peserta didiknya yang kurang memahami atau belum mengerti materi tersebut maka gurunya langsung membimbing peserta didiknya kembali sampai peserta didiknya mengerti dengan sendirinya. Oleh karena itu, guru harus mencari solusinya agar proses pembelajaran yang dilakukan dapat berjalan dengan baik dan menyenangkan.Salah satu solusinya yaitu guru dapat memberikan tugas kepada peserta didik baik pemberian tugas secara kelompok maupun individu.

Tugas yang diberikan secara kelompok biasanya ada peserta didik yang tidak mengerjakan tugas dan hanya ada 1 atau 2 orang saja yang mengerjakannya, sedangkan jika diberikan tugas secara individu maka pastinya peserta didik akan berusaha sendiri untuk mengerjakan tugas tersebut. Hal ini berdampak pada hasil belajar peserta didik, karena apabila peserta didik tidak belajar maka tidak akan ada pengembangan materi bahkan materi yang telah diajarkan terlupakan. Peserta didik yang tidak berusaha belajar akan berdampak pada hasil belajar peserta didik yang rendah.

Berdasarkan penelitian sebelumnya yang telah dilakukan oleh Aulia Hermawati dengan judul Perbedaan Hasil Belajar Matematika dengan Pemberian Tugas Secara Kelompok dan Individual Siswa Kelas VIII SMP Negeri 3 Kertosono yang dilakukan empat kali pertemuan menunjukkan bahwa terdapat perbedaan yang signifikan antara siswa yang diberi tugas secara kelompok dengan siswa yang diberi tugas secara individu. Selanjutnya, penelitian yang dilakukan oleh Dini Indriani dengan judul Perbandingan Prestasi Belajar Antara Siswa Yang Diberi Tugas Latihan Soal Secara Kelompok dengan Individual Pada Soal Uraian dalam Pembelajaran Matematika (Studi Eksperimen) yang dilakukan di MTs. ANNUR Cirebon pada kelas VIII menunjukkan terdapat perbedaan yang signifikan antara siswa yang diberi tugas secara kelompok dengan siswa yang diberi tugas secara individu.

Berbeda dengan hasil penelitian yang dilakukan oleh Aulia Hermawati dan Dini Indriani, penelitian yang dilakukan oleh Ellis Triastutik dengan judul Perbandingan Hasil Belajar Matematika Antara Yang Diberi Tugas Secara Kelompok dan Individu Siswa Kelas X SMU N 1 Gondang Tulangangung Tahun Ajaran 2003 menyatakan bahwa tidak terdapat perbedaan hasil belajar matematika antara siswa yang diberi tugas secara kelompok dengan siswa yang diberi tugas individu.

Dilihat dari beberapa hasil penelitian yang telah dilakukan peneliti sebelumnya ternyata hasil penelitian yang dilakukan oleh Ellis Triastutik berbeda dengan hasil penelitian yang telah dilakukan oleh Aulia Hermawati dan Dini Indriani, sehingga perlu diteliti ulang apakah terdapat perbedaan hasil belajar siswa yang diberi tugas secara kelompok dengan tugas secara individu. Oleh karena itu, peneliti tertarik untuk 
meneliti dan mengkaji kembali penelitian ini dengan mengangkat judul yaitu Perbandingan Hasil Belajar Matematika Antara Peserta Didik Yang Diberi Tugas Kelompok dengan Tugas Individu di Kelas IX MTs. Madani Alauddin Paopao Kabupaten Gowa.

\section{HASIL BELAJAR MATEMATIKA}

Hasil belajar matematika dapat dijelaskan dengan memahami dua kata yang membentuknya, yaitu "hasil belajar" dan "matematika" antara lain:

1. Djamarah dalam Rahma Fitri, dkk. (2014: h. 18) menjelaskan bahwa hasil belajar merupakan hal yang sangat penting dalam pendidikan dan dapat dipandang sebagai salah satu ukuran keberhasilan peserta didik dalam pendidikan di sekolah yang menyangkut pengetahuan, kecakapan atau keterampilan yang dinyatakan setelah penilaian. Hasil belajar ini dijadikan pedoman atau bahan pertimbangan dalam menentukan kemampuan peserta didik.Sedangkan, Nana Sudjana (2006: h. 22) menjelaskan bahwa hasil belajar adalah kemampuan-kemampuan yang dimiliki oleh siswa setelah ia menerima pengalaman belajarnya.

2. Ismail (2014: h. 48) menjelaskan bahwa matematika adalah ilmu yang membahas angka-angka dan perhitungannya, membahas masalah-masalah numerik, mengenai kuantitas dan besaran, mempelajari hubungan pola, bentuk dan struktur, sarana berpikir, kumpulan sistem, struktur dan alat. Sedangkan,Rahayu dalam Pramitha Sari (2017: h. 42) menjelaskan bahwa matematika merupakan salah satu mata pelajaran yang diberikan kepada semua peserta didik mulai dari sekolah dasar sampai perguruan tinggi untuk membekali peserta didik dengan kemampuan berpikir logis, analitis, sistematis, kritis, dan kreatif serta kemampuan bekerjasama.

Jadi, hasil belajar matematika adalah suatu proses penilaian secara keseluruhan dan kontinu setelah peserta didik mengalami pengalaman pembelajaran.

Alisuf Sabri dalam Lathifatul Amanati (2008: h. 21) menjelaskan beberapa faktor yang dapat mempengaruhi hasil belajar peserta didik, yaitu dapat dibagi dalam dua bagian baik faktor internal dan eksternal peserta didik. Faktor-faktor yang berasal dari luar diri peserta didik (eksternal) terdiri dari faktor lingkungan dan faktor instrumental, sedangkan faktor-faktor yang berasal dari dalam diri peserta didik (internal) adalah berupa faktor jasmani dan faktor psikologis pada diri peserta didik. Pendapat ini diperkuat dengan penjelasan Roestiyah dalam Lathifatul Amanati yaitu faktor internal ialah faktor yang timbul dari dalam diri anak itu sendiri, seperti kesehatan, rasa aman, kemampuan, minat dan sebagainya. Sedangkan, faktor eksternal, ialah faktor yang datang dari luar si anak, seperti kebersihan rumah, udara, lingkungan dan sebagainya.

Abdunasir Sideeg (2016: h. 163) menjelaskan bahwa tujuan hasil belajar terdiri dari: (1) menginformasikan siswa tentang apa pengetahuan dan keterampilan mereka akan memperoleh melalui kursus atau program studi; (2) memetakan hubungan antara kursus, program studi dan derajat; (3) memetakan pengembangan pengetahuan dan keterampilan pada setiap tingkat kurikulum; (4) menyediakan struktur untuk mengevaluasi proses belajar mengajar; dan (5) menginformasikan desain kurikulum dan praktek pedagogik. 
Adapun, klasifikasi hasil belajar terbagi menjadi tiga ranah dalam Nana Sudjana (2004: h. 49) yaitu ranah kognitif (penguasaan intelektual), ranah afektif (sikap dan nilai), dan ranah psikomotorik (kemampuan bertindak/berperilaku). Ketiga ranah ini harus nampak sebagai hasil belajar peserta didik di sekolah. Oleh sebab itu ketiga aspek/ranah tersebut harus dipandang sebagai hasil belajar peserta didik dari proses pembelajaran.Allen dan Friedman (2016: h. 165) mengemukakan bahwa pembelajaran afektif melintasi semua ranah belajar, menggabungkan pembelajaran kognitif dan perilaku selain mengeksplorasi nilai dan perasaan.

\section{PEMBERIAN TUGAS}

Ellis dalam Monireh Azimzadeh (2014: h. 97) menyatakan bahwa tugas adalah kegiatan yang menyerukan penggunaan bahasa terutama berarti berfokus. Kelebihan dari pemberian tugas menurut Sumantri dan Permana dalam Ikramullah (2016: h. 36) yaitu: (1) membuat peserta didik aktif; (2) meransang peserta didik belajar lebih banyak baik dekat dengan guru maupun jauh dari guru, di dalam sekolah maupun di luar sekolah; (3) membuat peserta didik bergairah belajar karena dapat dilakukan dengan bervariasi; (4) membina tanggung jawab dan disiplin peserta didik; serta (5) mengembangkan kreativitas peserta didik. Adapun, kelemahan dari pemberian tugas menurut Sumantri dan Permana dalam Ikramullah (2016: h. 36) yaitu: (1) sulit mengontrol peserta didik apakah belajar sendiri atau dikenakan orang lain; (2) sulit memberikan tugas yang sesuai dengan perbedaan individu peserta didik; (3) tugas yang monoton dapat membosankan peserta didik; dan (4) tugas yang banyak dan sering dapat membuat beban dan keluhan bagi peserta didik.

Untuk mengatasi kekurangan atau keterbatasan pemberian tugas tersebut, Arifa Tika Listiani (2014: h. 13) menjelaskan bahwa guru dapat melakukan cara yaitu: (1) tugas yang diberikan pada peserta didik hendaknya jelas; (2) memberi waktu yang cukup; (3) tugas yang diberikan harus diawasi secara sistematis; (4) tugas yang telah diserahkan pada guru harus dikoreksi dan diberi catatan-catatan perbaikan dan kemudian dikembalikan kepada peserta didik; serta (5) tugas yang diberikan hendaknya menarik minat peserta didik dan mendorong peserta didik untuk menyelesaikannya.

Aprilia Intan Permatasari, dkk. (2014: h. 119) menjelaskan bahwa tujuan dari pemberian tugas dalam proses belajar mengajar adalah memberi kesempatan kepada peserta didik untuk menyelidiki hal-hal yang berhubungan dengan materi yang sedang dipelajari, sehingga pengetahuan akan dapat diingat lebih lama.Budiarji dalam Hana Susanti (2013: h. 15-16) mengemukakan bahwa ada tiga hal yang perlu diperhatikan dalam pemberian tugas yaitu sistematika, relevansi tugas, dan waktu untuk melaksanakan tugas.

Noer Faizah (2009: h. 21-22) menjelaskan langkah-langkah yang harus diikuti dalam penggunaan metode pemberian tugas atau resitasi, yaitu:

1. Fase pemberian tugas yakni guru harus memperhatikan tujuan yang akan dicapai dari pemberian tugas tersebut, tugas harus sesuai kemampuan peserta didik, dan adanya petunjuk atau sumber yang dapat membantu pekerjaan peserta didik. 
2. Fase pelaksanaan tugas yakni guru harus memberikan bimbingan pada peserta didik agar tidak bertanya-tanya lagi apa yang harus dikerjakan, dan apa yang menjadi tugasnya.

3. Fase mempertanggung jawabkan tugas yakni peserta didik belajar (dengan melaksanakan tugas) sesuai dengan tujuan dan petunjuk-petunjuk guru. Fase resitasi adalah fase peserta didik mempertanggung jawabkan hasil belajarnya.

Dalam pelaksanaannya, pemberian tugas dapat diberikan secara individu dan kelompok yang dapat dijabarkan sebagai berikut.

\section{Pemberian Tugas Kelompok}

Saroni dalam Dwi Yustiani Sanjaya (2013: h. 9) menjelaskan bahwa tugas kelompok merupakan metode pembelajaran yang tidak meninggalkan peranan dari masing-masing peserta didik, peserta didik memegang peranan secara individu tetapi dikelompokkan sebagai tugas bersama untuk bertanggungjawab berinisiatif dan memiliki kreativitas sebagai tugas bersama. Carol Schmer, dkk. (2011: h. 349) mengungkapkan bahwa tugas kelompok mengharuskan peserta didik untuk belajar bersama dalam lingkungan tim. Selanjutnya, penelitian oleh Keyes dan Burns (2008: h. 362) menyimpulkan bahwa tugas kelompok memperbaiki pembelajaran peserta didik sambil mengembangkan kerja tim, komunikasi, dan keterampilan kepemimpinan yang penting. Peserta didik dalam penelitian ini percaya bahwa tugas kelompok membantu mereka mencapai lebih banyak dan memperbaiki pemahaman mereka tentang konsep utama.

Kelebihan dari pemberian tugas kelompok, salah satunya adalah peserta didik yang telah paham dan mengerti akan mengajari peserta didik yang belum paham, dengan kata lain sebagaimana telah dijelaskan dalam bukunya Ibrahim (2012: h. 50) yaitu peserta didik yang pandai dalam kelompok dapat membantu peserta didik yang lainnya dalam satu kelompoknya. Dari kelebihan pemberian tugas secara kelompok dapat terlihat bahwa peserta didik aktif dalam pembelajaran karena terjadi interaksi di antara peserta didik. Sedangkan, kelemahannya yaitu tidak semua anggota dalam satu kelompok mengerjakan tugas yang diberikan oleh guru, melainkan hanya 1 atau 2 orang saja yang mengerjakannya. Sehingga tidak terlihat kerjasama dalam kelompok.

\section{Pemberian Tugas Individu}

Fifin Faridlotul Umroh (2016: h. 3) menjelaskan bahwa metode tugas secara individu merupakan suatu cara mengajar yang dilakukan guru dengan memberikan tugas dan peserta didik melaksanakan tugas secara mandiri. Roestiyah (2001: h. 32) mengungkapkan bahwa salah satu kelebihan dari pemberian tugas individu yaitu sangat terlihat kemampuan masing-masing siswa dan kelemahannya yaitu dalam penyelesaian tugas kurang sempurna karena hasil belajarmya adalah hasil pemikiran perorangan.

\section{METODE PENELITIAN}

Pendekatan dalam penelitian ini adalah pendekatan kuantitatif yang datanya berupa angka-angka. Adapun, jenis penelitian yang digunakan yaitu penelitian kuasi eksperimen yaknipeneliti memilih dua kelas dengan perlakuan yang berbeda dianta- 
ranya kelas eksperimen I diberi perlakuan dengan pemberian tugas secara kelompok dan kelas eksperimen II diberi perlakuan dengan pemberian tugas secara individu. Populasi dalam penelitian ini adalah seluruh peserta didik kelas IX MTs. Madani Alauddin Paopao Kabupaten Gowa yang terdiri dari 92 orang. Sampelnya adalah kelas $\mathrm{IX}_{\mathrm{B}}$ yang terdiri dari 30 orang dan kelas IX $\mathrm{X}_{\mathrm{C}}$ yang yang terdiri dari 32 orang. Sehingga jumlah sampel dalam penelitian ini adalah 62 orang. Instrumen dari penelitian ini berupa pedoman dokumentasi, pedoman observasi, dan tes. Teknik analisis data yang digunakan adalah statistik deskriptif dan statistik inferensial.

\section{HASIL PENELITIAN DAN PEMBAHASAN}

\section{Analisis Deskriptif}

Deskriptif Hasil Belajar Matematika Peserta Didik Kelas IX $X_{B}$ Yang Diberi Tugas Secara Kelompok

Tabel 1. Statistik Deskriptif Kemampuan Awal Peserta Didik Kelas IX Descriptive Statistics

\begin{tabular}{|r|r|r|r|r|r|r|}
\hline & N & Range & Minimum & Maximum & Mean & Std. Deviation \\
\hline Kelas IX & 30 & 66 & 34 & 100 & 66,57 & 19,21 \\
\hline
\end{tabular}

Berdasarkan tabel1 diketahui bahwa rata-rata (mean) kemampuan awal peserta didik kelas $\mathrm{IX}_{\mathrm{B}}$ dari 30 orang adalah 66,57 dengan nilai maksimum 100, nilai minimum 34, dan nilai range adalah 66. Adapun, nilai standar deviasi (simpangan baku) dari tabel 4.1 adalah 19,21 yakni sebagian besar data tersebar/berjarak $\pm 19,21$ dari nilai rata-ratanya.

Tabel 2. Distribusi Frekuensi dan Persentase serta Pengkategorian Hasil BelajarMatematika Terhadap Kemampuan Awal Peserta Didik Kelas IX

\begin{tabular}{|l|l|c|c|}
\hline \multirow{2}{*}{ Kategori } & \multirow{2}{*}{ Interval } & \multicolumn{2}{c|}{$\begin{array}{c}\text { Kemampuan Awal Peserta Didik } \\
\text { Kelas I } \mathbf{X}_{\mathbf{B}}\end{array}$} \\
\cline { 3 - 4 } & & Frekuensi & Persentase (\%) \\
\hline Sangat Tinggi & $95 \leq \mathrm{x}$ & 2 & 6,67 \\
\hline Tinggi & $76 \leq \mathrm{x}<95$ & 11 & 36,67 \\
\hline Sedang & $57 \leq \mathrm{x}<76$ & 8 & 26,67 \\
\hline Rendah & $38 \leq \mathrm{x}<57$ & 7 & 23,33 \\
\hline Sangat Rendah & $38>\mathrm{x}$ & 2 & 6,67 \\
\hline \multicolumn{2}{|c|}{ Jumlah } & $\mathbf{3 0}$ & $\mathbf{1 0 0}$ \\
\hline
\end{tabular}

Berdasarkan tabel 2 diketahui bahwa terdapat 2 orang $(6,67 \%)$ berada pada kategori sangat tinggi, 11 orang $(36,67 \%)$ berada pada kategori tinggi, 8 orang $(26,67 \%)$ berada pada kategori sedang, 7 orang $(23,33 \%)$ berada pada kategori rendah, dan 2 orang $(6,67 \%)$ berada pada kategori sangat rendah.

Tabel 3. Statistik Deskriptif Kelas IX $\mathrm{X}_{\mathrm{B}}$ (Kelas Eksperimen I) Yang Diberi Tugas

Kelompok

Descriptive Statistics

\begin{tabular}{|l|c|c|c|c|c|c|}
\hline & $\mathrm{N}$ & Range & Minimum & Maximum & Mean & Std. Deviation \\
\hline KE. I & 30 & 53 & 37 & 90 & 75,53 & 14,457 \\
\hline
\end{tabular}


Berdasarkan tabel3 diketahui bahwa rata-rata (mean) nilai posttest peserta didik kelas $\mathrm{IX}_{\mathrm{B}}$ dari 30 orang adalah 75,53 dengan nilai maksimum 90, nilai minimum 37, dan nilai range adalah 53. Adapun, nilai standar deviasi (simpangan baku) dari tabel 4.1 adalah 14,457 yakni sebagian besar data tersebar/berjarak $\pm 14,457$ dari nilai rataratanya.

Tabel 4. Distribusi Frekuensi dan Persentase serta Pengkategorian Hasil Belajar Matematika Terhadap Nilai Post-test Peserta Didik Kelas $\mathrm{IX}_{\mathrm{B}}$ (Kelas Eksperimen I) dengan Perlakuan Yang Diberi Tugas Kelompok

\begin{tabular}{|l|l|c|c|}
\hline \multirow{2}{*}{ Kategori } & \multirow{2}{*}{ Interval } & \multicolumn{2}{c|}{ Nilai Post-test Peserta Didik Kelas IX $\mathbf{B}_{\mathbf{B}}$} \\
\cline { 3 - 4 } & & Frekuensi & Persentase (\%) \\
\hline Sangat Tinggi & $97 \leq \mathrm{x}$ & 0 & 0 \\
\hline Tinggi & $83 \leq \mathrm{x}<97$ & 13 & 43,33 \\
\hline Sedang & $68 \leq \mathrm{x}<83$ & 10 & 33,33 \\
\hline Rendah & $54 \leq \mathrm{x}<68$ & 4 & 13,33 \\
\hline Sangat Rendah & $54>\mathrm{x}$ & 3 & 10 \\
\hline \multicolumn{2}{|c|}{ Jumlah } & $\mathbf{3 0}$ & $\mathbf{1 0 0}$ \\
\hline
\end{tabular}

Berdasarkan tabel 4.4 diketahui bahwa tidak ada peserta didik yang berada pada kategori sangat tinggi, 13 orang $(43,33 \%)$ berada pada kategori tinggi, 10 orang $(33,33 \%)$ berada pada kategori sedang, 4 orang $(13,33 \%)$ berada pada kategori rendah, dan 3 orang $(10 \%)$ berada pada kategori sangat rendah.

Hasil belajar matematika peserta didik kelas $\mathrm{IX}_{\mathrm{B}}$ dapat disajikan dalam bentuk diagram batang yang dapat dilihat pada gambar 1 .

\section{Frekuensi Kemampuan Awal $\quad$ Frekuensi Nilai Posttest}

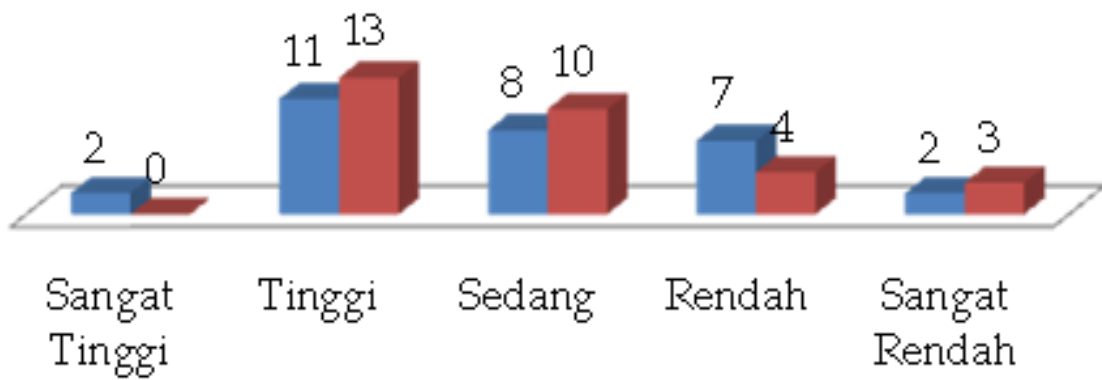

Gambar 1. Diagram Batang Hasil Kemampuan Awal dan Nilai Posttest Kelas IX

\section{Deskriptif Hasil Belajar Matematika Peserta Didik Kelas IX Yang Diberi Tugas Secara Individu}

Tabel 5. Statistik Deskriptif Kemampuan Awal Peserta Didik Kelas IX

\section{Descriptive Statistics}

\begin{tabular}{|l|r|r|r|r|r|r|}
\hline & N & Range & Minimum & Maximum & Mean & Std. Deviation \\
\hline Kelas IX $_{\mathrm{C}}$ & 32 & 88 & 10 & 98 & 72,97 & 20,292 \\
\hline
\end{tabular}

Berdasarkan tabel5 diketahui bahwa rata-rata (mean) kemampuan awal peserta didik kelas $\mathrm{IX}_{\mathrm{C}}$ dari 32 orang adalah 72,97 dengan nilai maksimum 98, nilai minimum 
10, dan nilai range adalah 66. Adapun, nilai standar deviasi (simpangan baku) dari tabel 4.4 adalah 20,292 yakni sebagian besar data tersebar/berjarak $\pm 20,292$ dari nilai rata-ratanya.

Tabel 6. Distribusi Frekuensi dan Persentase serta Pengkategorian Hasil Belajar Matematika Terhadap Kemampuan Awal Peserta Didik Kelas IX

\begin{tabular}{|l|l|c|c|}
\hline \multirow{2}{*}{ Kategori } & \multirow{2}{*}{ Interval } & \multicolumn{2}{c|}{$\begin{array}{c}\text { Kemampuan Awal Peserta Didik Kelas } \\
\text { IX }_{\mathbf{C}}\end{array}$} \\
\cline { 3 - 4 } & & Frekuensi & Persentase (\%) \\
\hline Sangat Tinggi & $150 \leq \mathrm{x}$ & 0 & 0 \\
\hline Tinggi & $99 \leq \mathrm{x}<150$ & 0 & 0 \\
\hline Sedang & $47 \leq \mathrm{x}<99$ & 29 & 90,625 \\
\hline Rendah & $-4 \leq \mathrm{x}<47$ & 3 & 9,375 \\
\hline Sangat Rendah & $-4>\mathrm{x}$ & 0 & 0 \\
\hline \multicolumn{2}{|c|}{ Jumlah } & $\mathbf{3 2}$ & $\mathbf{1 0 0}$ \\
\hline
\end{tabular}

Berdasarkan tabel 6 diketahui bahwa tidak ada peserta didik yang berada pada tiga kategori, seperti kategori sangat tinggi, kategori tinggi, dan kategori sangat rendah, tetapi terdapat 29 orang $(90,625 \%)$ yang berada pada kategori sedang, dan 3 orang $(9,375 \%)$ berada pada kategori rendah.

Tabel 7. Statistik Deskriptif Kelas IX $\mathrm{C}_{\mathrm{C}}$ (Kelas Eksperimen II) Yang Diberi Tugas Individu

Descriptive Statistics

\begin{tabular}{|l|c|c|c|c|c|c|}
\hline & $\mathrm{N}$ & Range & Minimum & Maximum & Mean & Std. Deviation \\
\hline KE. II & 32 & 50 & 30 & 80 & 51,50 & 15,954 \\
\hline
\end{tabular}

Berdasarkan tabel 7 diketahui bahwa rata-rata (mean) nilai posttest peserta didik kelas $\mathrm{IX}_{\mathrm{C}}$ dari 32 orang adalah 51,50 dengan nilai maksimum 80, nilai minimum 30, dan nilai range adalah 50. Adapun, nilai standar deviasi (simpangan baku) dari tabel 4.5 adalah 15,954 yakni sebagian besar data tersebar/berjarak $\pm 15,954$ dari nilai rataratanya.

Tabel 8. Distribusi Frekuensi dan Persentase serta Pengkategorian Hasil Belajar Matematika Terhadap Nilai Post-test Peserta Didik Kelas IX $X_{C}$ Sebagai Kelas Eksperimen II dengan Perlakuan Yang DiberiTugas Individu

\begin{tabular}{|l|l|c|c|}
\hline \multirow{2}{*}{ Kategori } & \multirow{2}{*}{ Interval } & \multicolumn{2}{c|}{ Nilai Post-test Peserta Didik Kelas IX $\mathbf{C}_{\mathbf{C}}$} \\
\cline { 3 - 4 } & & Frekuensi & Persentase (\%) \\
\hline Sangat Tinggi & $44 \leq \mathrm{x}$ & 18 & 56,25 \\
\hline Tinggi & $28 \leq \mathrm{x}<44$ & 14 & 43,75 \\
\hline Sedang & $12 \leq \mathrm{x}<28$ & 0 & 0 \\
\hline Rendah & $-4 \leq \mathrm{x}<12$ & 0 & 0 \\
\hline Sangat Rendah & $-4>\mathrm{x}$ & 0 & 0 \\
\hline \multicolumn{2}{|c|}{ Jumlah } & $\mathbf{3 2}$ & $\mathbf{1 0 0}$ \\
\hline
\end{tabular}

Berdasarkan tabel 4.8 dapat diketahui bahwa terdapat 18 orang $(56,25 \%)$ berada pada kategori sangat tinggi, 14 orang $(43,75 \%)$ berada pada kategori tinggi, dan tidak ada peserta didik yang berada pada tiga kategori, seperti kategori sedang, kategori rendah, dan kategori sangat rendah. 
Hasil belajar matematika peserta didik kelas IXC dapat disajikan dalam bentuk diagram batang yang dapat dilihat pada gambar 2 .

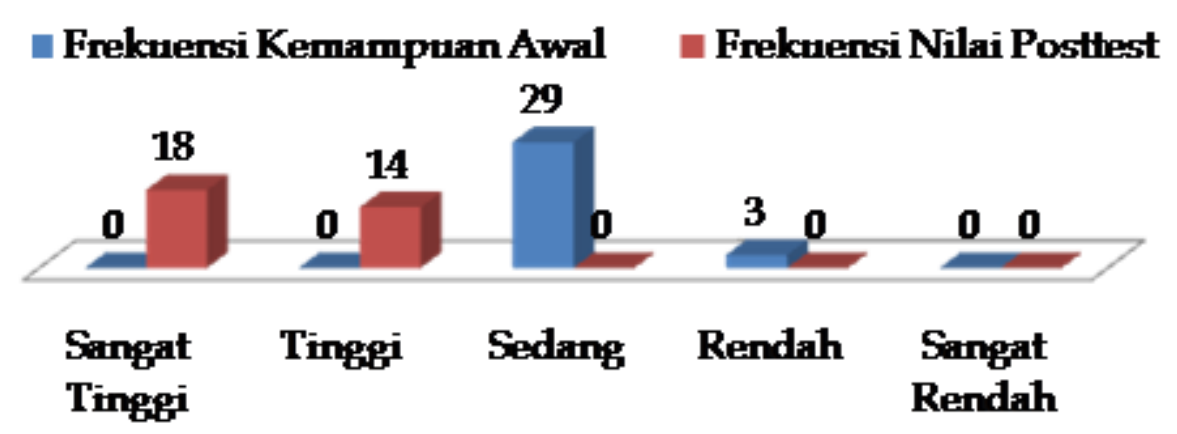

Gambar 2. Diagram Batang Hasil Kemampuan Awal dan Nilai Posttest Kelas IX

Perbandingan Hasil Belajar Matematika Peserta Didik Antara Yang Diberi Tugas Kelompok dengan Tugas Individu di Kelas IX MTs. Madani Alauddin Paopao Kabupaten Gowa

\section{Analisis Inferensial}

Dalam hal ini dilakukan uji prasyarat yaitu:

\section{Uji Normalitas}

Tabel 9. Uji Normalitas Kemampuan Awal Peserta Didik Kelas Eksperimen I

\begin{tabular}{|c|c|c|}
\hline \multicolumn{3}{|c|}{ One-Sample Kolmogorov-Smirnov Test } \\
\hline & & Kelas Eksperimen I \\
\hline \multicolumn{2}{|c|}{$\mathrm{N}$} & 30 \\
\hline \multirow{2}{*}{ Normal Parameters ${ }^{a, b}$} & Mean & 66,57 \\
\hline & Std. Deviation & 19,21 \\
\hline \multirow{3}{*}{ Most Extreme Differences } & Absolute & , 142 \\
\hline & Positive & 142 \\
\hline & Negative &,- 122 \\
\hline \multicolumn{2}{|l|}{ Kolmogorov-Smirnov Z } & 076 \\
\hline \multicolumn{2}{|l|}{ Asymp. Sig. (2-tailed) } &, 583 \\
\hline \multicolumn{3}{|c|}{ a. Test distribution is Normal. } \\
\hline \multicolumn{3}{|c|}{ b. Calculated from data. } \\
\hline
\end{tabular}

Berdasarkan tabel 9 diketahui bahwa nilai signifikan $\mathrm{p}=$ Asymp. Sig.(2-tailed) adalah $0,583>\alpha=0,05$ yang berarti data uji normalitas kemampuan awal peserta didik kelas eksperimen I berdistribusi normal. Sedangkan, hasil perhitungan uji normalitas data kemampuan awal peserta didik kelas eksperimen I secara manual dapat dilihat di lampiran E pada tabel E.9 yaitu diperoleh $D_{\text {hitung }}(\mathrm{Do})=0,145$. Selanjutnya, dari tabel pada $\alpha=0,05(n=30)$ diperoleh $D_{\text {tabel }}=0,248$. Ini berartiDo $<D_{\text {tabel }}$ dengan demikian $\mathrm{H}_{0}$ diterima atau data berdistribusi normal.

Tabel 10. Uji Normalitas Kemampuan Awal Peserta Didik Kelas Eksperimen II

\begin{tabular}{|l|r|}
\hline \multicolumn{2}{|c|}{ One-Sample Kolmogorov-Smirnov Test } \\
\hline & \multicolumn{1}{|c|}{ Kelas Eksperimen II } \\
\hline $\mathrm{N}$ & \\
\hline
\end{tabular}




\begin{tabular}{|l|l|r|}
\hline \multirow{2}{*}{ Normal Parameters ${ }^{\mathrm{a}, \mathrm{b}}$} & Mean & 72,97 \\
\cline { 2 - 3 } & Std. Deviation & 20,292 \\
\hline \multirow{3}{*}{ Most Extreme Differences } & Absolute &, 191 \\
\cline { 2 - 3 } & Positive &, 114 \\
\cline { 2 - 3 } & Negative &,- 191 \\
\hline Kolmogorov-Smirnov Z &, 114 \\
\hline Asymp. Sig. (2-tailed) &, 193 \\
\hline
\end{tabular}

a. Test distribution is Normal.

b. Calculated from data.

Berdasarkan tabel 10 diketahui bahwa nilai signifikan $\mathrm{p}=$ Asymp. Sig.(2-tailed) adalah 0,193 $>\alpha=0,05$ yang berarti data uji normalitas kemampuan awal peserta didik kelas eksperimen II berdistribusi normal. Sedangkan, hasil perhitungan uji normalitas data kemampuan awal peserta didik kelas eksperimen II secara manual dapat dilihat di lampiran E pada tabel E.10 yaitu diperoleh $D_{\text {hitung }}(\mathrm{Do})=0,114$. Selanjutnya, dari tabel pada $\alpha=0,05(n=32)$ diperoleh $D_{\text {tabel }}=0,240$. Ini berarti Do $<D_{\text {tabel }}$ dengan demikian $\mathrm{H}_{0}$ diterima atau data berdistribusi normal.

Tabel 11. Uji Normalitas Nilai Posttest Peserta Didik

\begin{tabular}{|l|l|r|r|}
\hline \multicolumn{5}{|c|}{ One-Sample Kolmogorov-Smirnov Test } \\
\hline \multicolumn{2}{|c|}{} & Kelas Eksperimen I & Kelas eksperimen II \\
\hline $\mathrm{N}$ & Mean & 75,53 & 32 \\
\hline \multirow{2}{*}{$\begin{array}{l}\text { Normal } \\
\text { Parameters }\end{array}$} & Std. Deviation & 14,457 & 51,50 \\
\hline \multirow{3}{*}{$\begin{array}{l}\text { Most Extreme } \\
\text { Differences }\end{array}$} & Absolute &, 274 & 15,954 \\
\cline { 2 - 4 } & Positive &, 159 &, 140 \\
\cline { 2 - 4 } & Negative &,- 274 &, 140 \\
\hline Kolmogorov-Smirnov Z &, 158 &,- 127 \\
\hline Asymp. Sig. (2-tailed) &, 220 &, 141 \\
\hline \multicolumn{2}{|l|}{ a. Test distribution is Normal. } \\
\hline b. Calculated from data.
\end{tabular}

Berdasarkan tabel 11 dapat ditarik kesimpulan:

a. Hasil uji normalitas nilai posttest kelas eksperimen I memiliki nilai signifikan $\mathrm{p}=$ Asymp. Sig. (2-tailed) yaitu 0,220 > $\alpha=0,05$ yang berarti data uji normalitas kemampuan awal peserta didik kelas eksperimen I berdistribusi normal. Adapun, hasil perhitungan uji normalitas nilai posttest peserta didik kelas eksperimen I secara manual dapat dilihat di lampiran E pada tabel E.12 yaitu diperolehD $D_{\text {hitung }}(\mathrm{Do})=$ 0,158 . Sedangkan, dari tabel pada $\alpha=0,05(n=30)$ diperoleh $D_{\text {tabel }}=0,248$. Ini berarti Do $<\mathrm{D}_{\text {tabel }}$ dengan demikian $\mathrm{H}_{0}$ diterima atau data berdistribusi normal.

b. Hasil uji normalitas nilai posttest kelas eksperimen II memiliki nilai signifikan $\mathrm{p}=$ Asymp. Sig. (2-tailed) yaitu 0,553 $>\alpha=0,05$ yang berarti data uji normalitas kemampuan awal peserta didik kelas eksperimen II berdistribusi normal. Adapun, hasil perhitungan uji normalitas nilai posttest peserta didik kelas eksperimen II secara manual dapat dilihat di lampiran E pada tabel E.13 yaitu diperolehD $D_{\text {hitung }}(\mathrm{Do})=$ 0,141 . Sedangkan, dari tabel pada $a=0,05(n=32)$ diperoleh $D_{\text {tabel }}=0,240$. Ini berarti $\mathrm{Do}<\mathrm{D}_{\text {tabel }}$ dengan demikian $\mathrm{H}_{0}$ diterima atau data berdistribusi normal. 


\section{Uji Homogenitas}

Tabel 12. Hasil Uji Homogenitas Kemampuan Awal Peserta Didik Kelas IX Antara Yang Diberi Tugas Kelompok dengan Tugas Individu

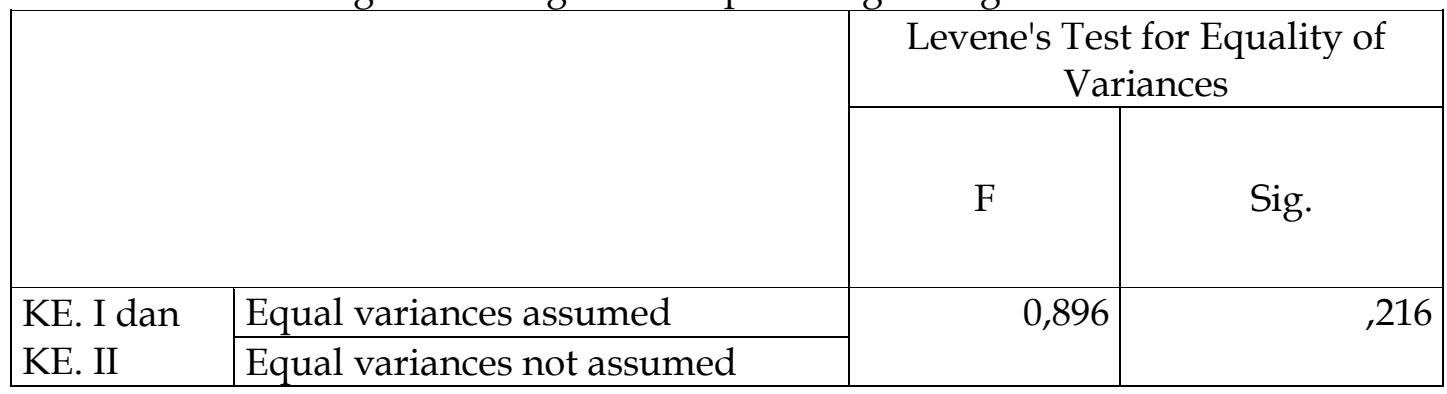

Berdasarkan tabel 12 diperoleh nilai $\mathrm{F}_{\text {hitung }}=0,896$ dan nilai Sig. $=0,216$. Dengan demikian, nilai probabilitas (nilai Sig.) lebih besar dari nilai taraf signifikan $(\alpha=0,05)$, sehingga dapat disimpulkan bahwa data kedua kelas memiliki variansi yang sama (homogen).

Tabel 13. Hasil Uji Homogenitas Nilai Posttest Peserta Didik Kelas IX Antara Yang Diberi Tugas Kelompok dengan Tugas Individu

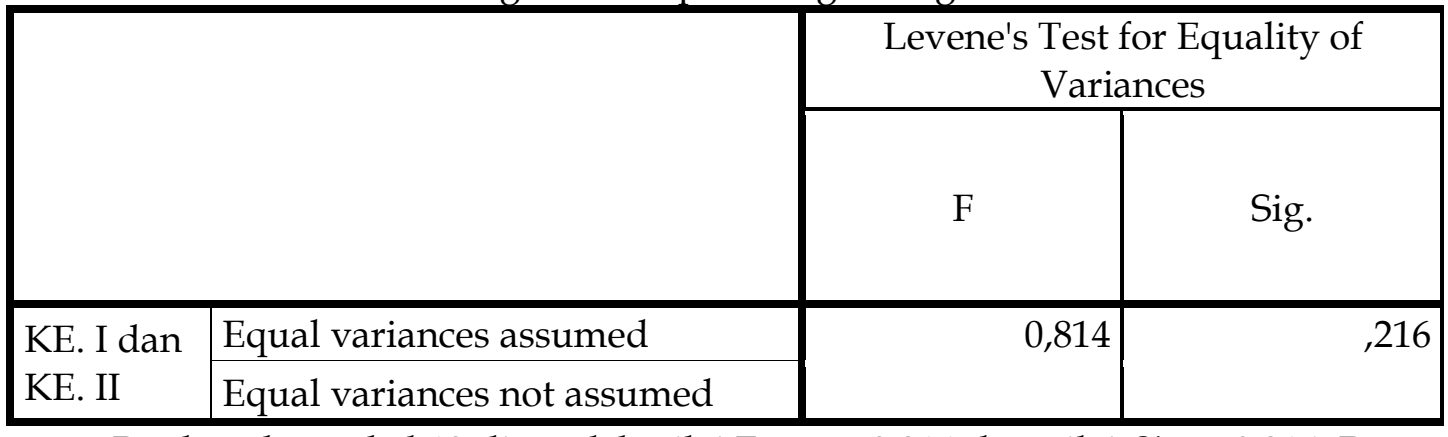

Berdasarkan tabel 13 diperoleh nilai $\mathrm{F}_{\text {hitung }}=0,814$ dan nilai Sig. $=0,216$. Dengan demikian, nilai probabilitas (nilai Sig.) lebih besar dari nilai taraf signifikan $(\alpha=0,05)$, sehingga dapat disimpulkan bahwa data kedua kelas memiliki variansi yang sama (homogen).

\section{Pengujian Hipotesis}

Tabel 14. Hasil Uji Hipotesis Posttest

\begin{tabular}{|l|c|c|c|c|c|c|c|}
\hline \multicolumn{1}{|c|}{ Independent Samples Test } \\
\hline $\begin{array}{c}\text { Tevene's for } \\
\text { Equality } \\
\text { of } \\
\text { Variances }\end{array}$ \\
\hline F
\end{tabular}




\begin{tabular}{|c|c|c|c|c|c|c|c|c|c|c|}
\hline \multirow{2}{*}{$\begin{array}{l}\text { KE. I } \\
\text { dan } \\
\text { KE. II }\end{array}$} & $\begin{array}{l}\text { Equal } \\
\text { variances } \\
\text { assumed }\end{array}$ & $\underset{\infty}{\not}$ & $\begin{array}{l}\stackrel{0}{\sim} \\
\end{array}$ & 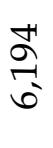 & 8 & 8 & 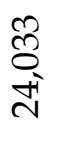 & $\begin{array}{l}\frac{1}{2} \\
\text { o. } \\
n^{-1}\end{array}$ & 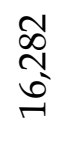 & $\begin{array}{l}\frac{1}{\infty} \\
\stackrel{-}{\infty} \\
\frac{1}{2}\end{array}$ \\
\hline & $\begin{array}{l}\text { Equal } \\
\text { variances } \\
\text { not } \\
\text { assumed }\end{array}$ & & & $\begin{array}{l}\text { హ゙ } \\
\text { స̆ }\end{array}$ & $\begin{array}{l}\text { హ゙ } \\
\text { જे }\end{array}$ & 8 & $\begin{array}{l}\tilde{~} \\
\text { Oे } \\
\stackrel{+}{N}\end{array}$ & $\begin{array}{l}\text { రి } \\
\infty \\
\text { ") }\end{array}$ & 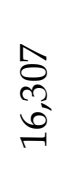 & $\begin{array}{l}8 \\
\stackrel{8}{-} \\
\infty\end{array}$ \\
\hline
\end{tabular}

Nilai $t_{\text {hitung }}$ dibandingkan dengan nilai $t_{\text {tabel }}$ yaitu kelas eksperimen I dan kelas eksperimen II memiliki derajat kebebasan yakni dk $=n_{1}+n_{2}-2=30+32-2=60$. Dengan $\mathrm{dk}=60$ dan taraf kesalahan 5\%, maka $t_{\text {tabel }}=2,000$ (uji dua pihak dan dengan interpolasi). Dalam hal ini $t_{\text {hitung }}>t_{\text {tabel }}(6,194>2,000)$ sehingga $\mathrm{H}_{0}$ ditolak dan $\mathrm{H}_{1}$ diterima.

\section{PROSES PEMBELAJARAN}

Penelitian ini menggunakan lembar observasi untuk mengamati kegiatan peserta didik baik yang diberi tugas kelompok maupun individu. Adapun, hasil pelaksanaan proses pembelajaran peserta didik dapat dilihat dilampiran pada lembar observasi yang dapat dijabarkan sebagai berikut:

1. Selama penerapan tugas kelompok yang dilakukan peserta didik sebanyak 3 kali pertemuan diperoleh hasil yaitupada pertemuan pertama dengan tingkat penguasaan $74 \%$ berada pada kategori cukup, pertemuan kedua dengan tingkat penguasaan $79 \%$ berada pada kategori cukup, serta pertemuan ketiga dengan tingkat penguasaan $84 \%$ berada pada kategori baik, sehingga terlihat bahwa peserta didik sudah banyak mengalami kemajuan, mampu bekerjasama dengan baik, dan telah menguasai materi dengan baik.

2. Selama penerapan tugas individu yang dilakukan peserta didik sebanyak 3 kali pertemuan diperoleh hasil yaitu pada pertemuan pertama dengan tingkat penguasaan $62 \%$ berada pada kategori kurang, pertemuan kedua dengan tingkat penguasaan $67 \%$ berada pada kategori kurang, serta pertemuan ketiga dengan tingkat penguasaan $70 \%$ berada pada kategori cukup, sehingga terlihat bahwa peserta didik sudah banyak mengalami kemajuan dengan memahami soal-soal yang diberikan oleh guru dan mampu menyelesaikannya sendiri dengan baik.

Berdasarkan hasil kegiatan yang dilakukan oleh peserta didik di atas dapat disimpulkan bahwa tingkat penguasaan peserta didik yang diberi tugas kelompok berada pada kategori cukup dan baik. Sedangkan, tingkat penguasaan peserta didik yang diberi tugas individu berada pada kategori kurang dan cukup. Sehingga, pemberian tugas kelompok lebih baik dibandingkan pemberian tugas individu.

\section{PEMBAHASAN}

Penelitian ini bertujuan untuk mengetahui perbedaan hasil belajar matematika antara peserta didik yang diberi tugas kelompok dengan peserta didik yang diberi tugas individu. Untuk mengukur hasil belajar peserta didik digunakan instrumen dalam bentuk tes, yaitu diberikannya tes akhir (posttest) dengan perlakuan yang berbeda yaitu kelas $\mathrm{IX}_{\mathrm{B}}$ diberi perlakuan dengan pemberian tugas kelompok dan kelas IX $\mathrm{X}_{\mathrm{C}}$ di- 
beri perlakuan dengan pemberian tugas individu, serta menggunakan instrumen pedoman dokumentasi untuk mengambil nilai ulangan harian semester 1 sebagai data kemampuan awal peserta didik.

Setelah dilakukannya penelitian diperoleh hasil analisis statistik deskriptif yaitu peserta didik kelas $\mathrm{IX}_{\mathrm{B}}$ memiliki nilai rata-rata kemampuan awal 66,57 dan nilai ratarata posttest 75,53 . Sedangkan, kelas $\mathrm{IX}_{\mathrm{C}}$ memiliki nilai rata-rata kemampuan awal yaitu 72,97 dan nilai rata-rata posttest 51,50. Adapun, hasil analisis data inferensial yaitu uji normalitas dan homogenitas dari kedua kelas yang digunakan sebagai sampel penelitian adalah normal dan homogen, sehingga untuk pengujian hipotesis digunakan uji $\mathrm{t}$ (independent sample $t$-test) diperoleh $t_{\text {hitung }}=6,194>t_{\text {tabel }}=2,000$ dengan nilai sig.(2tailed) $<$ a atau $0,000<0,05$, sehingga $\mathrm{H}_{0}$ ditolak artinyaterdapat perbedaan yang signifikan hasil belajar matematika peserta didik kelas IX MTs. Madani Alauddin Paopao Kabupaten Gowa antara yang diberi tugas kelompok dengan tugas individu.

Hasil penelitian ini sejalan dengan penelitian sebelumnya yang telah dilakukan Aulia Hermawati dalam penelitiannya yang berjudul Perbedaan Hasil Belajar Matematika dengan Pemberian Tugas Secara Kelompok dan Individual Siswa Kelas VIII SMP Negeri 3 Kertosono yang menjelaskan bahwa terdapat perbedaan yang signifikan antara siswa yang diberi tugas secara kelompok dengan siswa yang diberi tugas secara individu. Penelitian yang dilakukan oleh Dini Indriani yang berjudul Perbandingan Prestasi Belajar Antara Siswa Yang Diberi Tugas Latihan Soal Secara Kelompok dengan Individual Pada Soal Uraian dalam Pembelajaran Matematika (Studi Eksperimen) yang dilakukan di MTs. ANNUR Cirebon pada kelas VIII yang menjelaskan bahwa terdapat perbedaan yang signifikan antara siswa yang diberi tugas secara kelompok dengan siswa yang diberi tugas secara individu.

Adanya perbedaan hasil belajar matematika tersebut disebabkan oleh perbedaan pemberian tugas yang digunakan memiliki kelemahan dan kelebihan tertentu. Pemberian tugas secara berkelompok dalam Ibrahim (2012: h. 50) yaitu tidak semua anggota dalam satu kelompok mengerjakan tugas yang diberikan oleh guru, melainkan hanya 1 atau 2 orang saja yang mengerjakannya. Sehingga tidak terlihat kerjasama dalam kelompok. Adapun, kelebihan dari pemberian tugas secara berkelompok yaitu peserta didik yang telah paham dan mengerti akan mengajari peserta didik yang belum paham, dengan kata lain sebagaimana telah dijelaskan dalam bukunya Ibrahim yaitu peserta didik yang pandai dalam kelompok dapat membantu peserta didik yang lainnya dalam satu kelompoknya. Dari kelebihan pemberian tugas secara kelompok dapat terlihat bahwa peserta didik aktif dalam pembelajaran karena terjadi interaksi di antara peserta didik. Selanjutnya, dalam Roestiyah (2001: h. 32) telah dijelaskan bahwa pemberian tugas secara individu memiliki kelebihan yaitu dapat membuat peserta didik lebih aktif dalam pembelajaran karena peserta didik mengerjakan tugas yang diberikan dengan usahanya sendiri dan lebih bertanggungjawab terhadap penyelesaian tugasnya tanpa bantuan orang lain, sedangkan kelemahannya yaitu peserta didik akan merasa malas untuk menyelesaikannya apabila tugas tersebut kurang diminati peserta didik dan sukar dikerjakan karena hasil pemikiran perorangan.

\section{SIMPULAN}

Berdasarkan hasil pengujian hipotesis yang diajukan dan pembahasan yang dilakukan dalam penelitian ini, maka dapat diambil kesimpulan sebagai berikut: 
1. Hasil belajar matematika peserta didik kelas IX yang diberi tugas secara kelompok memiliki persentase sebesar 13 orang $(43,33 \%)$ berada pada kategori tinggi, 10 orang $(33,33 \%)$ berada pada kategori sedang, 4 orang $(13,33 \%)$ berada pada kategori rendah, 3 orang $(10 \%)$ berada pada kategori sangat rendah, dan nilai rata-rata yang diperoleh sebesar 75,53.

2. Hasil belajar matematika peserta didik kelas IX yang diberi tugas secara individu memiliki persentase sebesar 18 orang $(56,25 \%)$ berada pada kategori sangat tinggi, 14 orang $(43,75 \%)$ berada pada kategori tinggi, dan nilai rata-rata sebesar 51,50.

3. Terdapat perbedaan yang signifikan antara hasil belajar matematika peserta didik yang diberi tugas secara kelompok dengan peserta didik yang diberi tugas secara individu.

\section{DAFTAR PUSTAKA}

Allen, K. N. \& Bruce, D. F. (2010). “Affective Learning: A Taxonomy for Teaching Social Work Values." Journal of Social Work Values and Ethics, vol. 7 no. 2: h. 1-12.

Amanati, L. (2008). Pengaruh Pemberian Umpan Balik Terhadap Motivasi Belajar Matematika Siswa. Skripsi. Jakarta: Jurusan Pendidikan Agama Islam, Fakultas Ilmu Tarbiyah dan Ilmu Keguruan, Universitas Islam Negeri (UIN) Syarif Hidayatullah.

Azimzadeh, M. (2014). "The Effects of Task Repetition on The Fluency, Accuracy and Complexity of Turkish efl Learner' Oral Production." International Journal of Language Academy, vol. 2: h. 95-108.

Faizah, N. (2009). Upaya Meningkatkan Kemampuan Pemecahan Masalah Matematika Siswa dengan Metode Resitasi. Skripsi. Jakarta: Jurusan Pendidikan Matematika, Fakultas Ilmu Tarbiyah dan Keguruan, Universitas Islam Negeri Syarif Hidayatullah.

Fitri, Rahma, Helma \& Hendra, S. (2014). "Penerapan Strategi The Firing LinePada Pembelajaran Matematika Siswa Kelas XI IPS SMA Negeri 1 Batipuh." Jurnal Pendidikan Matematika, vol. 3 no. 1: h. 18-22.

Hermawati, A. (2008). Perbedaan Hasil Belajar Matematika dengan Pemberian Tugas Secara Berkelompok dan Individual Siswa Kelas VIII SMPN 3 Kertosono. Skripsi, Malang: Jurusan Pendidikan Matematika, Fakultas MIPA, Universitas Negeri Malang. Error! Hyperlink reference not valid. (Diakses 13 Mei 2012).

Ibrahim. Evaluasi Pendidikan. (2012). Jakarta: Rineka Cipta.

Ikramullah. (2016). Perbandingan Hasil Belajar dan Kreativitas Siswa Yang Diberi Tugas Kelompok dengan Siswa Yang Diberi Tugas Individu dalam Mata Pelajaran Geografi Kelas IX SMA Negeri 1 Unggul Darul Imarah. Skripsi. Banda Aceh: Jurusan Pendidikan Geografi, Fakultas Keguruan dan Ilmu Pendidikan, Universitas Syiah Kuala.

Indriani, D. "Perbandingan Prestasi Belajar Matematika Antara Siswa Yang Diberi Tugas Latihan Soal Secara Kelompok Dengan Individual Pada Soal Uraian Dalam Pembelajaran Matematika (Studi Eksperimen di Kelas VIII MTs ANNUR Kota Cirebon)." Skripsi. Fakultas Tarbiyah IAIN Syekh Nurjati Cirebon.

Ismail dkk. (2014). "Kapita Selekta Matematika," dalam Ali Hamzah dan Muhlisraini, eds. Perencanaan dan Strategi Pembelajaran Matematika. Cet. II; Jakarta: Rajawali Pers.

Keyes, M, \& Kylie, B. (2008). “Group Learning in Law.” Journal Tittle: Griffith Law Review, vol. 17 no. 1: h. 356-382.

Listiani, A. T. (2014). Hubungan Antara Metode Pemberian Tugas dengan Prestasi Belajar Siswa Pada Mata Pelajaran Bahasa Arab di Kelas VIII MTs. Al Futuhiyyah Bumirejo Wonosobo Tahun Ajaran 2013/2014. Skripsi. Yogyakarta: Jurusan Pendidikan Bahasa Arab, Fakultas Ilmu Tarbiyah dan Keguruan, Universitas Islam Negeri Sunan Kalijaga. 
Permatasari, Aprilia, I., Bakti, M., \& Nanik, D. N. (2014). “Efektivitas Penggunaan Model Pembelajaran Joyful Learningdengan Metode Pemberian Tugas Terhadap Prestasi Belajar Siswa Pada Materi Pokok Koloid Siswa Kelas XI IPA SMA Negeri 1 SIMO Tahun Pelajaran 2012/2013." Jurnal Pendidikan Kimia (JPK), vol. 3. no. 1: h. 117-122.

Pulungan, I. (2015). "Penggunaan Metode Penugasan Kelompok Pada Workshop Bedah SKL Guru IPA MTs. Se Kabupaten Serdang Bedagai,"Official Website of Dra. Hj. Intan Pulungan, M.Pd. https://sumut2.kemenag.go.id/files/sumut/file/file/TULISANPENGAJAR/nadb1428569773.pdf (27 Januari 2015).

Roestiyah. (2001). Strategi Belajar Mengajar. Jakarta: Rineka Cipta.

Sanjaya, D. Y. (2013). Perbedaan Kemandirian Siswa dalam Belajar Matematika Melalui Pemberian Tugas Secara Kelompok dan Individual Kelas VII SMP Negeri 7 Salatiga. Skripsi, Salatiga: Jurusan Pendidikan Matematika, Universitas Kristen Satya Wacana. Fakultas Keguruan dan Ilmu Pendidikan.

Sari, P. (2017) "Pemahaman Konsep Matematika Siswa Pada Materi Besar Sudut Melalui Pendekatan PMRI". Jurnal Gantang, vol. 2 no. 1, Maret 2017: h. 41-50.

Schmer, Carol, Peggy, W. S., \& Jane, P. (2011). "Learning Outcomes Associated with Group Assignments." Journal of Online Learning and Teaching, vol. 7 no. 3, September 2011: h. 349-353.

Sideeg, A. (2016). “Bloom's Taxonomy, Backward Design, and Vygotsky's, Zone of Proximal Development in Crafting Learning Outcomes." International Journal of Linguistics, vol. 8. no. 2: h. 158-186.

Sudjana, N. (2004). Dasar-dasar Proses Belajar mengajar. Cet VII; Bandung: Sinar Baru Algesindo.

Sudjana, N. (2006). Penilaian Hasil Proses Belajar Mengajar. Cet. 11; Bandung: PT Remaja Rodakarya.

Susanti, H. (2013). Penerapan Metode Pemberian Tugas Menggunakan Mind Mapping Untuk Meningkatkan Hasil Belajar IPA Siswa Kelas V SDN 008 Kualu Kecamatan Tambang Kabupaten Kampar. Skripsi, Riau: Jurusan PGMI, Fakultas Tarbiyah dan Keguruan, Universitas Islam Negeri Sultan Syarif Kasim Riau.

Umroh, F. F . (2016). Pengaruh Metode Pemberian Tugas Secara Kelompok dan Metode Pemberian Tugas Secara Individu Pada Materi Sistem Persamaan Linier Dua Variabel (SPLDV) Terhadap Hasil Belajar Siswa Kelas VIII SMPN 1 Mojo Kediri. Skripsi, Kediri: Jurusan Pendidikan Matematika, Fakultas Keguruan dan Ilmu Pendidikan, Universitas Nusantara PGRI. 